\title{
Impact of global financial crunch on financially innovative microfinance institutions in South Asia
}

\author{
Faisal Mustafa, Ambreen Khursheed ${ }^{*}$ (1) and Maham Fatima
}

\author{
* Correspondence: ambreen \\ khursheed@ucp.edu.pk \\ UCP Business School, Faculty of \\ Management Studies, University of \\ Central Punjab, Lahore, Pakistan
}

\begin{abstract}
The wave of global financial crises (2008-2009) caused a surge in the capital flows of developed countries particularly, between developed and developing countries. The crunch hit all financial sectors with unanticipated severity. The study evaluates the role of a country's political practices in moderating the impact of global financial crunch on microfinance performance. Using the fixed effect panel regression method on the dataset comprising of 95 MFls operating in South Asia from 2003 to 2012, we determine that microfinance operational capability shares a positive relationship with the institutional attributes of a country and our output reveals that impact of country's political practices is pervasive on the financial output of MFIs, liable to different levels of implementation. The findings further reveals that MFIs situated in countries having vigorous political practices are less severely affected by the economic crunch.
\end{abstract}

Keywords: Global financial crunch, South Asia, Microfinance institutions

JEL classification codes: $F 6, F 65, G 21$

\section{Introduction}

This study examines microfinance performance within the global financial crunch period of (2008-2009) and, specifically, the impact of the political practices in moderating crunch effects on their performance. Currently, microfinance institutions (MFIs) are diffusing all over the world but at the same time it is rapidly changing with new innovative opportunities (Moro Visconti, 2011; Hartarska, 2005). From the last decade, microfinance institutions began to appear as more commercial and this commercialization is growing at a speedy rate (Silva and Chavez, 2015). The commercial banks in advanced and developing economies play an evolving role in funding MFIs. In Pakistan few private commercial banks have transformed into MFIs. However, in other countries like Nepal, Thailand and Malaysia there are several projects for transforming commercial banks into MFIs (Dokulilova, 2009; Janda et al., 2014; Krauss, 2011).

The technological advancement of microfinance has also extended the conventional services of MFIs. The microfinance institutions conventionally focus on microcredit, specifically small loans to the poor (O’Donohoe, 2009). At present there is a significant

(c) The Author(s). 2018 Open Access This article is distributed under the terms of the Creative Commons Attribution 4.0 International License (http://creativecommons.org/licenses/by/4.0/), which permits unrestricted use, distribution, and reproduction in any medium, provided you give appropriate credit to the original author(s) and the source, provide a link to the Creative Commons license, and indicate if changes were made. 
shift of microcredit institutes into MFIs offering innovative customized services (Chowdry, 2011; Moro Visconti, 2011). This broader term reveals the fact that microfinance is not only focused to provide loans but it is also dedicated to update its services in terms of latest technology (Silva and Chavez, 2015). Furthermore, latest banking expertise like ATMs, online banking services, internet and charge cards have started to join the microfinance sector, assisting the investors and enhancing banking services (Havemann, 2009).

The funding condition of MFIs has also started to transform quickly. Conventionally, MFIs were mainly supported by public and private donors or aid institutes (Aemiro and Mekonnen, 2012). Currently, international commercial banks and donors have become more interested in financing MFIs that are offering innovative services to their customers. The first example of MFI with commercial capitalization was the establishment of an investment fund known as Profound and it raised 23 million dollars to finance MFIs operating in Latin America (CGAP, 2007).

In the present era, technical and social innovation exerts a deep impact on microfinance institutions and it also contributes in reshaping their business model (Moro Visconti, 2011). For mitigating risk factors in microfinance institutions, innovation works as an opportunity in view of its persistent impact on the investment risk factors (Aemiro and Mekonnen, 2012). MFIs are considered as an effective and innovative measure of poverty alleviation as it provides various financial services to poor borrowers who require a small amount of money to finance their micro-businesses (Kneiding, 2009). Therefore, microfinance can be recognized as a tool of economic innovation with a goal to combat poverty. At present thousands of microfinance institutions (MFIs) are operating with ranging from self-help groups to established commercial banks providing various financial services to millions of microbusinesses (Dokulilova, 2009). These MFIs are supported by not only the donor agencies, but also by many philanthropists, investors, network organizations, lenders, management consulting firms, and many other specialized businesses and all these organizations collectively form the flourishing global microfinance industry (Gonzalez, 2011; Wagner, 2013).

Microfinance has developed as an essential tool for poverty alleviation from the past two decades and its idea was first launched in 1970 when Dr. Yunus of Grameen Bank (Nobel laureate) started interest free micro loans to poor people (Karanshawy, 2007). At present, a huge number of institutes are providing microfinance services in South Asia including a huge number of Non- Governmental Organization, Microfinance Banks, Rural Support Programs, Non- Banking Financial Institutions and others (Pakistan Microfinance Network, 2014). A research by Chowdry (2011) explained that MFIs are the best proven channel of credit delivery to the small and medium households of economy but due to the global financial crunch not only the financial sector but also the MFIs of South Asia went through a very harsh period.

\section{Background of global financial crunch}

The economy of South Asia showed an impressive growth during the first half of 2000s (Khawaja \& Ghani, 2012). But in 2008 the world economy confronted its most dangerous catastrophe since the Great Depression of the 1930s (O'Donohoe, 2009). The crunch began in 2007, when in the United States sky-high home prices finally turned resolutely downward, spread rapidly, initially it effected entire financial sector of U.S. and then it reached financial markets overseas (Olson and Zoubi, 2016). However, 
the South Asian economy faced greater inflationary pressure in the crunch period with an increase in food prices, severe power shortage and a slowdown in the services and manufacturing sector. Ultimately, the microfinance sector also faced a shock in its balance sheet as on the liability side, all types of donors were badly influenced due to a sudden drop in liquidity and on the assets side, due to the worsening of macroeconomic conditions the loan delinquency and write offs also began to increase (Badiola, 2009). The crunch and recession also affected the poverty reduction goals of developing countries in South Asia as the crunch lead to rising unemployment and collapsing of financial institutions made it more difficult to tackle as compare to the past recession of 1980s (Littlefield, 2009).

\section{Significance of the study}

This paper examines the moderating role of country's political practices on the impact of global financial crunch on the performance of financially innovative South Asian MFIs by using fixed effect panel data regression method. Previous research studies have not attempted so far to analyze such issue; rather they were more focused to investigate efficiency of MFIs by comparing their internal costs, interest rates, and profitability (Rosenberg, Gonzalez and Sushma, 2009) or determining the effect of macroeconomic factors on microfinance performance (Ahlin, Lin and Maio, 2011).

\section{Literature review}

The South Asian countries depicts a completely different landscape for financial insertion with focusing on a specific and unique history showing growth of financial markets. The inspiring story of microfinance institutions which initiated 40 years ago from Bangladesh continues to flourish as a potential across the whole South Asia.

There are a limited number of researches focusing on the significant effects of global financial crunch specifically felt by low-income people served by South Asian MFIs. However, few key studies that examined microfinance performance in view of economic shocks includes researches by Gonzalvez (2007), Krauss and Walter (2009) and Ahlin and Lin (2006). These studies have analyzed different versions of MixMarket dataset, determined the vulnerability of MFIs to macro-economic changes. As, Ahlin and Lin (2006) and Gonzalvez (2007) examined the practical resilience of MFIs during macroeconomic surprises, Krauss and Walter (2009) revealed the impact of domestic and international shocks on MFIs. Researchers like Ahlin and Lin (2006) analyzed 112 MFIs selected from 48 countries and analyzed their potential for the period of 1994-2004 by using panel regressions. They targeted four key performance measures: default rates, self-sustainability, borrowers' cost and clientele growth rate. Their study indicated that macro-economic shocks are major factors to effect MFI operations and this questions the potential of investment in MFIs during period of crunch. In addition to this, they also highlighted that MFI key performance indicators also play a significant part in MFI success.

Past studies have also confirmed that the key performance indicators of MFIs' are highly dependent on the consistently improving financial innovations in the microfinance sector. As, financial innovation is a vital piece of the monetary action; e.g. financial development has brought about systemic changes in the financial 
framework through the enhancement of financial services and adjusted installment frameworks (Michalopoulos et al. 2011), features of new and existing financial products, new financial markets and financial institutions (Simiyu et al. 2014). It has also shifted public perceptions and brought innovative transformations in government policies (Mwinzi 2014). Financial advancement can happen with different financial innovations, for example, the expansion of banking sector and the capital markets. A well-functioning banking sector and capital market improves economic growth (Ndako 2010) through capital development, the proficient allotment of resources and by setting up a link between surplus and deficit units. As per Adusei, (2013) well established capital markets and banks both play a vital role in feasible evenhanded development by permitting gainful investing (Bakang 2016). As a result, economic development flourishes. Similarly, a research by Duasa, (2014) revealed that financial development through the improvements in the banking sector can cause economic development and also assist in poverty reduction. As advanced financial sector permits individuals to access more institutional credit for financing (Uddin and Chakraborty 2014). A study has also highlighted the role of financial innovation in mitigating the investment risk factors in MFIs such as Helwig L. Swinkels L. (2015), investigated publically registered MFIs with market based and accounting based risk indicators with spanning tests and found that financial innovation significantly reduces the investment risk factors in MFIs. On the similar lines, Galema et al. (2011), used mean variance spanning tests and suggested that investors can avoid risk of investment by investing in a MFI offering financially innovative services with well dispersed credit portfolio.

A past research of Janda and Svarovska (2010), highlighted the importance of financial innovation as they determined that $50 \%$ of all reserves generated by microfinance institutes are transferred by specific financial channels. These specific institutes are most commonly known as microfinance investment vehicles - MIVs that plays a key role in the finance sector if they are technologically updated.

In addition to the importance of financial innovation a few researchers have also highlighted the influence of the economic conditions of a country on the operations of MFIs. As, a key research of Gonzalvez (2007) exposed that changes in domestic gross national income - GNI influences MFI portfolio performance. The study analyzed four key indicators - portfolio at risk over 90 days and over 30 days, write off ratio and loan loss rate of 639 MFIs selected from 88 countries from 1999 to 2006. The study used panel regressions with fixed and random effects and revealed a significant relationship between GNI and MFI performance. On the similar lines, Krauss and Walter (2009) assessed correlation of MFIs with domestic and international market performance indicators. Their dataset covered period of 1998-2006 and considered 325 MFIs based in 66 countries. They adopted panel regression technique for analyzing the MFI returns using selected key financial variables. Their results revealed that MFIs are not vulnerable to domestic and international market shocks.

\section{Research gap bridged by the study}

Past research studies have only focused on the benefits of investing in microfinance by considering the correlations between the financial indicators of microfinance institutes. In our opinion, the methodology adopted in other papers is quite restrictive. However, 
this study fills the research gap as its primary objective is to examine whether a country's political practices moderates the influence of global financial crunch on the performance of South Asian innovative MFIs by using fixed effects panel data regression method. This methodology has the capability to accurately determine the casual interference of unobserved variables and thus, it is quite useful for investigating the role of socially innovative financial features in enhancing the potential of MFIs to survive under economic shocks.

\section{Hypothesis of the study}

H1: Innovative microfinancing services are positively correlated with their performance during crunch period.

The MFIs uses innovative management techniques in developed credit markets in order to make smooth loan repayments. The innovative features includes the use of innovative customized loan repayment methods, innovative renewable energy products, innovative agri-products and services, innovative commercial and Islamic leasing services and branchless banking services. Therefore, we will examine whether the MFIs offering technologically advanced services were less intensely affected by the global financial crunch.

H2: Robust political practices of a country positively influence microfinance performance and enhances their resilience during crunch period.

The robust political regulations protect rights of investors and assist in contract enforcement to boost the financial performance of MFIs and also provides strength to resist the economic shocks. Thus, this study investigates whether a country's political regulations assist microfinance sector to endure the effects of financial crunch.

If both hypotheses of the study are proved then we may consider microfinance sector as a class of assets that is well equipped to face the economic shocks and is well prepared to grasp the attention of both commercially inclined financial institutes and socially responsible donors (McCluskey, Rausser 2003).

\section{Methodology}

\section{Selection of sample}

The selection of MFIs is based on the data of South Asian MFIs from Microfinance Information Exchange - MIX Market. As Mix Market is a source which provides most authentic information with the aim to stimulate information flow and investment in the microfinance sector (Mix Market, 2016).The dataset is from 2003 to 2012, though, our emphasis is on the performance of MFIs from the period of (2008-2009) global crunch, we selected our sample of MFIs registered with MIX during that nine-year duration which includes 4 years before the crunch (2003-2007), crunch period of 2 years (2008-2009), and the 3 years of post- crunch period (2010-2012). Our final sample includes 95 MFIs from South Asia for the 2003-2012 period. South Asia includes eight countries which are Bhutan, Sri-Lanka, Afghanistan, India, Bangladesh, Maldives, Nepal and Pakistan. Table 1 represents sample description by country, it depicts number of MFIs, credit portfolio size analyzed as gross loan portfolio (GLP) in USD millions and the total number of active borrowers in thousands (TNABs). Data is reported at the 
Table 1 Sample Description of South Asian MFls

\begin{tabular}{llll}
\hline Countries & No. of MFIs & GLP & TNABS \\
\hline Afghanistan & 4 & 79 & 66 \\
India & 24 & 2861 & 18,627 \\
Pakistan & 18 & 147 & 1114 \\
Nepal & 11 & 141 & 448 \\
Bhutan & 1 & 28 & 52 \\
Maldives & 8 & 102 & 207 \\
Sri-Lanka & 13 & 152 & 324 \\
Bangladesh & 16 & 2579 & 18,460 \\
Total & 95 & 6089 & 39,298 \\
\hline
\end{tabular}

end of year 2012. The table also reveals that MFIs working in South Asia has an excellent outreach with 39.3 million borrowers.

\section{Microfinance performance measuring indicators}

The study evaluates the financially innovative operations of MFIs in terms of their credit improvement, quality of portfolio and sustainability. The study analyze the financial sustainability by operational autonomy (OA) that is the most commonly used indicator for measuring performance of MFIs as the self-reliance is one of the key objective of most of the MFIs (Hartarska and Nadolnyak 2007). Therefore, instead of taking into account profitability methods like return on equity or return on assets, we focus on the operational independence by considering operation profit to manage their expenses. $\mathrm{OA}$ is calculated as a ratio of economic revenue to total cost on yearly basis. If the ratio is greater than 1 it shows MFI can manage its cost through its revenues earned. Table 2 shows MFIs in the sample were operationally independent from 2003 to 2012.

One of the key MFI performance indicator is the growth rate taken on annual basis represented by gross loan profit and it is calculated by taking log-difference of the real gross portfolio values on yearly basis. It is also the most wide used measure of credit improvement in the previous research studies (Ahlin, Lin, and Maio 2010; Wagner 2012 and Di Bella 2011). As a MFI can improve its dollar credit portfolio by outreaching maximum number of clients or by increasing its portfolio limit.

Table 2 Explanation of Financial Measures

\begin{tabular}{|c|c|c|c|c|c|c|c|}
\hline Financial measures & Description & 25 th $\%$ & 75th \%o & SD & Median & Mean & N \\
\hline $\mathrm{OA}$ & $\begin{array}{l}\text { Financial revenue / (Financial cost + } \\
\text { ruination loss + operating cost) }\end{array}$ & 1.05 & 1.41 & 0.49 & 1.14 & 1.18 & 2942 \\
\hline WOR & $\begin{array}{l}\text { Amount of loans written off over } \\
\text { the period/average of GLP }\end{array}$ & $0.04 \%$ & $2.02 \%$ & $4.1 \%$ & $0.88 \%$ & $2.6 \%$ & 2683 \\
\hline PAR & $\begin{array}{l}\text { Amount of loans overdue more } \\
\text { than } 30 \text { days/ GLP }\end{array}$ & $2.3 \%$ & $7.9 \%$ & $8.5 \%$ & $4.4 \%$ & $6.8 \%$ & 2630 \\
\hline GLP & $\begin{array}{l}\text { Log difference in Gross Loan } \\
\text { Portfolio (year-end) }\end{array}$ & $10 \%$ & $44.9 \%$ & $31.3 \%$ & $25.1 \%$ & $29.5 \%$ & 2859 \\
\hline TNABs growth & Log difference in TNABs (yearly) & $0.79 \%$ & $28.9 \%$ & $31.7 \%$ & $14.3 \%$ & $18.4 \%$ & 2781 \\
\hline Loan size growth & $\begin{array}{l}\text { Log difference in average loan balance } \\
\text { per debtor (yearly) }\end{array}$ & $21.48 \%$ & $25.2 \%$ & $23.1 \%$ & $10.2 \%$ & $12.3 \%$ & 2894 \\
\hline
\end{tabular}


We in this study follow Ahlin, Lin, and Maio (2010) by considering two growth indicators: growth in average loan limit and growth in the total number of active borrowers (TNABs). TNABs is analyzed as the log-difference in TNABs, however, growth in credit limit is assessed as log-difference in the average loan balance per active debtor (year-end).

Table 2 represents annual gross loan portfolio (GLP) rate for the selected sample of the MFIs is approx. 29\% however, a huge difference is present amidst the highest and the lowest quintiles which are increasing annually with the rate of $44 \%$ and $10 \%$. Moreover, table depicts that how an increase in GLP for the selected period can lead to both the average growth of $18.4 \%$ in the TNABs and the growth of $12.3 \%$ in average loan portfolio. The most commonly used measure for the quality of the portfolio is portfolio at risk over 30 days (Rosenberg, 2009). The portfolio at risk (PAR) is evaluated as the outstanding loan balance that are over than 30 days, represented as the percentage of total value of outstanding loans.

Table 3 depicts a mean (median) portfolio at risk of $6.8 \%$ (4.4\%), of MFIs with the maximum and minimum quintiles with a PAR ratio of $7.9 \%$ and $2.3 \%$. PAR ratio highlights that segment of the portfolio that is riskier and not being repaid and therefore, is an indication of expected defaults (Gonzalez, 2007). Write off ratio is calculated as the percentile of the borrowed funds written off within year. Table 2 represents the mean (median) value of write of ratio for the sample is $2.6 \%(0.88 \%)$ and it shows significantly less variation than the corresponding portfolio at risk ratios.

This paper follows Demirguc-kunt, Gupta and Detragiache (2007) methodology regarding bank behavior covering the period of banking crunch. This research study examines the influence of global financial crunch on the MFIs' performance with a regression methodology estimation for the crunch period (2008-2009). The coefficient

Table 3 Data Description at Country-Level

\begin{tabular}{|c|c|c|c|c|c|c|}
\hline $\begin{array}{l}\text { Country-level } \\
\text { variables }\end{array}$ & Definition & Mean & Median & SD & 75th\% & 25 th\% \\
\hline \multicolumn{7}{|c|}{ Country political practice measures } \\
\hline ACPPI & Average of three dimensions of political practices & 35.5 & 35.9 & 10.3 & 41.3 & 26.7 \\
\hline Corruption & Management & $\begin{array}{l}\text { The } \\
\text { limit } \\
\text { to }\end{array}$ & $\begin{array}{l}\text { which } \\
\text { public } \\
\text { power } \\
\text { is } \\
\text { utilized } \\
\text { for }\end{array}$ & & & \\
\hline \multirow{2}{*}{$\begin{array}{l}\text { achieving } \\
\text { private } \\
\text { interests and } \\
\text { profits. }\end{array}$} & 30.9 & 30.2 & 13.9 & 46.5 & 20.2 & \\
\hline & Accountability & & $\begin{array}{l}\text { Extent } \\
\text { of }\end{array}$ & & & \\
\hline $\begin{array}{l}\text { citizens' } \\
\text { partnership in } \\
\text { the selection } \\
\text { of their } \\
\text { government } \\
\text { freedom of } \\
\text { speech and } \\
\text { media rights }\end{array}$ & 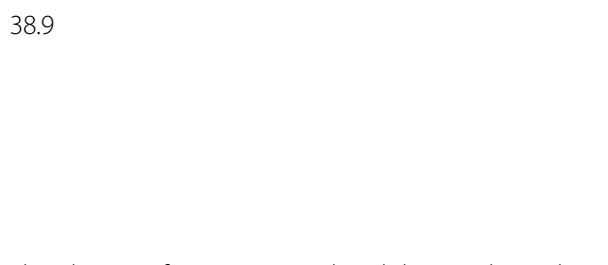 & 41.9 & 15.6 & 53.2 & 26.9 & \\
\hline $\begin{array}{l}\text { Political } \\
\text { stability }\end{array}$ & $\begin{array}{l}\text { The chance of government destabilization by violent } \\
\text { measures }\end{array}$ & 25.1 & 23.3 & 15.2 & 31.9 & 12.1 \\
\hline
\end{tabular}

Sources: The World Bank, World Development Indicators and World Governance Indicators 
estimate of crunch dummy analysis is the mean difference in the performance of MFIs during the crunch and the pre-crunch period (2003-2007). For evaluating MFIs performance the study incorporates a political practice indicator (PPI) and an interaction term between the political practice indicator and the crunch period dummy (PPI $x$ Crunch). The coefficient estimate with the interaction term assess the impact of country's political practice on the performance vulnerability of MFIs to the crunch. To resolve the problem of heterogeneousness in the features of MFIs, the framework is analyzed with fixed effects method with panel data regression and our model is as follows:

$$
\begin{aligned}
\text { MFI Financial Performance }=\beta_{0} & +\beta_{1}(\text { crunch period })+\beta_{2}(\text { post-crunch period }) \\
& +\beta_{3}(\mathrm{PPI})+\beta_{4}(\mathrm{PPI} \times \text { Crunch })+\varepsilon
\end{aligned}
$$

The countries' political practice variables are most commonly used as worldwide governance indicators which are available from World Bank. For assessing the political practices prevailing within a country we have considered 3 dimensions: Corruption Management, Accountability and Political Permanence, the study also includes average of all country's political practice indicator (ACPPI) as a rapid indicator of overall quality of political practices. Table 3 represents a report of each variable and descriptive statistics for all the selected MFIs as our sample. Previous research studies that comprises of political stability factors for analyzing MFI performances are Assefa, Hermes, and Meesters (2013) and Ahlin et al., (2010). We analyzed our model using ACPPI and each of the three single dimensions.

\section{Results}

The estimation output of our regression model is shown in Table 4 with average of three dimensions of political practices, ACPPI is the indicator of average political practices in a country. The first performance measure examined the sustainability of MFIs. Operational autonomy (OA) is highly influenced by the financial crunch. The coefficient of crunch shows that OA reduces on average by greater than 15 percentage points as compare to its pre-crunch stage. However, it is of lesser magnitude, a

Table 4 MFI performance affected by political practices of selected countries by fixed effect

\begin{tabular}{|c|c|c|c|c|c|c|}
\hline \multicolumn{7}{|c|}{ Regressed variable } \\
\hline & $\mathrm{OA}$ & $\begin{array}{l}\text { Gross loan } \\
\text { portfolio }\end{array}$ & WOR & PAR & $\begin{array}{l}\text { TNABs } \\
\text { growth }\end{array}$ & $\begin{array}{l}\text { Loan size } \\
\text { growth }\end{array}$ \\
\hline a & $\begin{array}{l}0.0227 \\
(1.0555)\end{array}$ & $1.7320(0.7802)$ & $\begin{array}{l}0.0527 \\
(0.1046)\end{array}$ & $\begin{array}{l}0.0304 \\
(0.1689)\end{array}$ & $\begin{array}{l}2.2891 \\
(0.7605)\end{array}$ & $\begin{array}{l}-0.4724 \\
(0.5478)\end{array}$ \\
\hline Crunch & $\begin{array}{r}-0.1528 \\
(0.0391)\end{array}$ & $-0.2751(0.0421)$ & $\begin{array}{l}0.0160 \\
(0.0075)\end{array}$ & $\begin{array}{l}0.0310 \\
(0.0102)\end{array}$ & $\begin{array}{l}-0.1853 \\
(0.0405)\end{array}$ & $\begin{array}{l}-0.1266 \\
(0.0302)\end{array}$ \\
\hline Post-crunch & $\begin{array}{l}-0.1161 \\
(0.0293)\end{array}$ & $-0.2374(0.0180)$ & $\begin{array}{l}0.0122 \\
(0.0024)\end{array}$ & $\begin{array}{l}0.0363 \\
(0.0052)\end{array}$ & $\begin{array}{l}-0.1735 \\
(0.0185)\end{array}$ & $\begin{array}{r}-0.0665 \\
(0.0142)\end{array}$ \\
\hline ACPPI & $\begin{array}{l}0.0061 \\
(0.0021)\end{array}$ & $0.014(0.0023)$ & $\begin{array}{l}0.0007 \\
(0.0003)\end{array}$ & $\begin{array}{r}-0.0009 \\
(0.0007)\end{array}$ & $\begin{array}{l}0.0145 \\
(0.0023)\end{array}$ & $\begin{array}{l}-0.0018 \\
(0.0020)\end{array}$ \\
\hline $\begin{array}{l}\text { ACPPI x } \\
\text { crunch }\end{array}$ & $\begin{array}{l}0.0021 \\
(0.0011)\end{array}$ & $0.0017(0.0011)$ & $\begin{array}{r}-0.0005 \\
(0.0002)\end{array}$ & $\begin{array}{c}-0.0005 \\
(0.0003)\end{array}$ & $\begin{array}{l}0.0011 \\
(0.0010)\end{array}$ & $\begin{array}{l}0.0007 \\
(0.0008)\end{array}$ \\
\hline $\mathrm{R}^{2}$ & 0.392 & 0.391 & 0.312 & 0.390 & 0.353 & 0.198 \\
\hline Observations & 2913 & 2860 & 2672 & 2729 & 2790 & 2784 \\
\hline
\end{tabular}
method with ACPPI as political practice indicator

The table represents the output of fixed effect method applied for analyzing the performance of MFIs as in eq. 1 by using the crunch and post crunch dummies in addition to the alpha value, $\mathrm{R}^{2}$ and total observations of all performance regression is shown. The values of standard errors are presented in parenthesis 
weakening in sustainability is also depicted in post-crunch level. The coefficient of political practice variable and the interaction term between country's political practices and crunch (ACPPI $x$ Crunch) is statistically positive and significant at $6 \%$.

Therefore, the output reveals that MFIs located in politically robust countries have the potential to perform better in regard to financial sustainability and the political practices moderates the impact of crunch on the progress of MFIs. The GLP rates depict that the crunch had a significant impact on the loan portfolio's growth rate. During the crunch period the growth rate of GLP reduced on average by greater than 27 percentage points. The output also confirms a huge impact on capability of MFIs to increase their loan limits. However, the interaction term of political practices and crunch is not significant. Therefore, the output reveals lesser effect of political practices on the GLP during the crunch as compare to before and after the crunch period. Likewise, a reduction in portfolio limit was observed due to reduction in TNABs and loan size. A decrease in borrowers by 18 percentage points and of loan size by 12 percentage points is disclosed in crunch period. The value of PAR shows an increase in the crunch period. The value of PAR is 3.10 points greater than pre-crunch level and it maintains is higher position during post-crunch stage. The value of average country's political practices shares a considerable moderating impact on microfinance performance during crunch. Hence, our results are in accordance to the previous results that performance of MFIs enhances when economy is in its boom phase. Lastly, the results of WOR shows that loan defaults considerably increase during crunch period and maintains high position even after the crunch. Summarizing all results, we find that the crunch had a huge impact on the financial performance, portfolio size growth and the sustainability of MFIs. Our output supports the findings of previous research studies of Wagner (2012) and Di Bella (2011) that also determined that the financial system was significantly affected by the crunch. Our results are also in line with Ahlin, Lin, and Maio (2010)'s previous study on MFIs' performance (1996 to 2007). Our study also reveals that macroeconomic conditions as also a considerable effect on MFIs. Furthermore, our output reveals a positive link between political practices in a country and microfinance performance and in terms of PAR we find that MFIs operating in countries in more politically stable environment have lesser chances of loan defaults. This output supports the research of Rajan and Zingales (1998) and Johnson (2000) who found that legal rights and robust political system during a crunch period enhances the capability of financial institutes to manage the crunch effects.

\section{Conclusion}

This paper investigates the moderating role of political practices of the countries on the performance of South Asian MFIs specifically during the period of financial crunch from 2008 to 2009. The findings of our paper are in line with (Di Bella 2011; Krauss and Walter 2009; Wagner 2012; Cull et al, 2007) that the MFIs were badly affected by the significant shocks of financial crunch. The output further reveals that MFIs located in countries having robust political regulations were more resistant to the financial crunch effects. Specifically, the political stability, a dimension of political practice is very important during the most uncertain period of crunch. Hence, government policies with long-term view point is the key factor during the uncertain environment created by the crunch. Similarly, the study also reveals that the noticeable progress of 
MFIs towards commercialization is enhanced with the adoption of more technologically advanced innovative services (see e.g., Gilberto M. Llanto and Ryu Fukui, 2003). Thus, the findings of this paper enriches our understanding of the impact of the financial crunch on microfinance sector of South Asia.

Our findings are in favor of the argument that countries focusing on more investment for the improvement of politically regulated environment are more efficient to reduce the susceptibility of their financial institutes from unexpected financial catastrophes (Rajan and Zingales, 1998). The findings of the study recommend that governments, by developing efficient policies and by providing financially secure environment to MFIs and their clients, can play a key role in boosting the outreach and economies of scale. Considering the increasing integration of MFIs into worldwide financial sector and its subsequently amplified susceptibility to universal financial crunch, our results suggest that robust political practices and efficient innovative features in the microfinance sector are now more significant than before. Our paper also provides future research directions as in this paper only formal institutes are analyzed as opposed to informal organizations like social norms, traditions and customs etc., therefore, future exploration could be done by considering informal institutes in investigating their performance and their sensitivity to financial crunch.

Abbreviations

ACPPI: Average Country Political Practice Indicator; GLP: Gross Loan Portfolio; MFIs: Microfinance Institutions; OA: Operational Autonomy; PAR: Portfolio at Risk; PPI: Political Practice Indicator; TNABs: Total number of Active Borrowers; WOR: Write off Ratio

Availability of data and materials

The data used in this study is obtained from Mix market website: http://www.themix.org/mixmarket

\section{Authors' contributions}

Dr. FM, Ms. AK and Ms. MF are the authors who made substantial contributions to conception and design, and/or acquisition of data, and/or analysis and interpretation of data. No one, other than the authors listed above, have contributed substantially to the writing and revising of the manuscript. All authors read and approved the final manuscript.

\section{Competing interests}

The authors whose names are listed below certify that they have NO affiliations with or involvement in any organization or entity regarding any financial and non-financial interest.

Received: 8 February 2018 Accepted: 26 June 2018

Published online: 04 July 2018

\section{References}

Adusei M (2013) Financial development and economic growth: evidence from Ghana. Int J Bus Finance 3(1):61-75

Aemiro T, Mekonnen D (2012) The financial performance and sustainability of microfinance institutions during the current financial crunch: the case of Amhara credit and saving institution (ACSI) in Ethiopia. Int J Bus Public Manag 2(2):81-87

Ahlin, C., J. Lin and M. Maio (2010). "Where does Microfinance Flourish: Microfinance Institution Performance in Macroeconomic Context". J Dev Econ 1(28):27-38.

Ahlin C, Lin J, Maio M (2011) Where does microfinance flourish? Microfinance institution performance in macroeconomic context. J Dev Econ 95(2):105-120

Ahlin, Christian \& Lin, Jocelyn. (2006). Luck or Skill? MFls' Performance in Macroeconomic Context. An Econometric Analysis of MFI Asset Quality, MIX Discussion Paper No. 1.

Assefa E, Hermes N, Meesters A (2013) Competition and the performance of microfinance institutions. Appl Financ Econ 23(9):767-782. https://doi.org/10.1080/09603107.2012. 75454.

Badiola L (2009) The impact of global financial crisis on rural and microfinance in Asia, Discussion Paper No. $2009-24$. Philippine Institute for Development Studies: Makati City.

Bakang MLN (2016) Effects of financial deepening on economic growth in Kenya. Int J Bus Commer 4(7):1-50

Chowdry, B. (2011). NBFI and Modaraba: an important segment of financial industry

Cull R, Demirgu“ c-kunt A, Morduch J (2007) Financial Performance and Outreach: A Global Analysis of Leading Microbanks. Econ J 117(517):F107-F133. https://doi.org/10.1111/j.1468-0297.2007.02017

Di Bella, C. G. (2011). The impact of the global financial crisis on microfinance and policy implications. IMF Working Papers, 1-40. Available at SSRN: https://ssrn.com/abstract=1899576 
Demirgüç-Kunt, Gupta, P., and Detragiache, E., (2007). 'Finance in lower-income countries: An empirical exploration', International Monetary Fund Working Paper. 2(41):147-160.

Dokulilova, L. J. (2009). Sustainability of microfinance institutions in financial crunch. MPRA, 1-25.

Duasa J (2014) Financial development and economic growth: the experiences of selected OIC countries. Int J Econ Manag 8(1):215-228 Economy, Vol. 20, No. 4, pp.1-23

Duflos, Eric, Alexia Latortue, Rochus Mommartz, Graham Perrett, and Stefan Staschen. Country-Level Effectiveness and Accountability Review with a Policy Diagnostic, Pakistan, CGAP. April 2007. http://www.cgap.org/portal/site/CGAP/ menuitem.69b24ba808b7799167808010591010a0/.

Galema R, Lensink R, Spierdijk L (2011) International diversification and microfinance. Int Money Financ 30(3):507-515

Gonzalez, A. (2007) Resilience of Microfinance Institutions to National Macroeconomic Events: An Econometric Analysis of Asset Quality. Discussion Paper. Washington, DC: Microfinance Information Exchange

Gonzalez A (2011) Lessons for strengthening microfinance institutions through financial crises, fluctuations in food and fuel prices, and other major risks. Micro Banking Bulletin, pp 1-14

Hartarska V (2005) Governance and performance of microfinance institutions in central and Eastern Europe and the newly independent states. World Dev 33(10):1627-1643. https://doi.org/10.1016/j.worlddev.2005.06.001

Hartarska, V., \& Nadolnyak, D. (2007). Do regulated microfinance institutions achieve better sustainability and outreach: Cross-country evidence. Applied Economics, 39(10):1207-1222.

Havemann J. (2009). The financial crunch of 2008: year in review 2008

Helwig L, Swinkels L (2015) Accounting for market risk in microfinance investments. Int J Sustain Econ 7(4):262-279

Janda, K., Rausser, G. and Svárovská, B. (2014) Can investment in microfinance funds improve risk-return characteristics of a portfolio?' Journal of Technological and Economic Development of Economy 20:673-695

Janda K, Svárovská B (2010) Investing into microfinance. J Bus Econ Manag 11(3):483-510

Johnson, S. (2000) Gender impact assessment in microfinance and microenterprise: Why and how, Development in Practice. 10:1, 89-94. https://doi.org/10.1080/09614520052547

Karanshawy, H. (2007). Finance Plus: A model for the activation of microfinance and medium finance. International Conference on Inclusive Islamic Financial Sector Development, University Brunei Darussalam. Management international/International Management/Gestĩ̃3n Internacional 15(3):57-69.

Khawaja I, Ghani E (2012) Global financial crunch: policy implications for Pakistan. NUML Journal of Management \& Technology 9(1):20-31

Kneiding CE (2009) Shedding light on microfinance equity valuation: past and present. CGAP Occas Pap 14(1):1-40

Krauss (2011) Can microfinance reduce portfolio volatility? Econ Dev Cult Chang 58(1):85-110

Krauss N, Walter I (2009) Can microfinance reduce portfolio volatility? Econ Dev Cult Chang 58:85-110. https://doi.org/ $10.2139 /$ ssrn. 943786

Littlefield E (2009) The global financial crunch and its impact on microfinance. CGAP Focus Nots 52(1):1-8 Retrieved from Focus Note, World Bank

Llanto GM, Fukui R (2003) Innovations in microfinance in Southeast Asia. Philippine Institute for Development Studies Research Paper Series 12(2):1-30.

Michalopoulos S, Laeven L, Levine R (2011) Financial innovation and endogenous growth. National Bureau of Economic Research, USA, pp 1-33

Mixmarket. (2016). Mixmarket-Datasets. Retrieved from https://www.themix.org/mixmarket/datasets. Accessed 12 May 2017

Moro Visconti R (2011) Global recession and microfinance risk governance in developing countries. Risk Gov Control J 1(3):17-30

Mwinzi DM (2014) The effect of financial innovation on economic growth in Kenya. (master of business administration). University of Nairobi (D61/ 60882/2013), Kenya

Ndako UB (2010) Financial Development, Economic Growth, and Stock Market Volatility: Evidence from Nigeria and South Africa. (Doctor of Philosophy). University of Leicester, South Africa

O'Donohoe (2009) Shedding light on microfinance equity valuation: past and present. Available at SSRN 2619149, pp 1-40

Olson D, Zoubi T (2016) Convergence in bank performance for commercial and Islamic banks during and after the global financial crunch. Q Rev Econ Financ 4:42

Pakistan Microfinance Network. 2014 Annual Report. Pakistan Microfinance Network. Retrieved from http://www.pmn. org.pk/assets/articles/e95eafccaaf580a11254137df5012ef7.pdf. Accessed 26 Aug 2017

Rajan R, Zingales L (1998) Which capitalism? Lessons from the east Asian crisis. J Appl Corp Financ 11(3):40-48. https:// doi.org/10.1111/j.1745-6622.1998.tb00501.

Rosenberg R., Gonzalez A., Sushma N. S. (2009): The New Moneylenders: Are the Poor Being Exploited by High Microcredit Interest Rates? No. 15.

Rausser, J. M. (2003). Stigmatized Asset Value: Is It Temporary or Long-Term? The Review of Economics and Statistics, 85(2):276-285.

Silva AC, Chavez AG (2015) Microfinance, country governance, and the global financial crunch. Ventur Cap 2(1):191-213

Simiyu RS, Ndiang'ui PN, Ngugi CC (2014) Effect of financial innovations and operationalization on market size in commercial banks: a case study of equity Bank, Eldoret branch. Int J Bus Soc Sci 85(1):227-250

Uddin, M. G. S., \& Chakraborty, L. (2014). International trade, financial development and economic growth Nexus in Bangladesh: empirical evidence from time series approach

Wagner C (2012) From boom to bust: how different has microfinance been from traditional banking? Dev Pol Rev 30(2):187-210. https://doi.org/10.1111/j.1467-7679.2012. 00571.

Wagner W, Adalbert C (2013) The vulnerability of microfinance to financial turmoil-evidence from the global financial crunch. World Development 51(11):71-90 